\title{
ДИНАМІКА МАРКЕРІВ ФІБРИНОЛІЗУ У ПАЦІЄНТІВ З ПІДВИЩЕНИМ ІНДЕКСОМ МАСИ ТІЛА ПРИ ПОЛІТРАВМІ
}

\author{
к. мед. н. Кучерявченко В. В., \\ проф., д. мед. н. Волкова Ю. В., \\ к. мед. н. Шарлай К. Ю.
}

Украйна, Харків, Харківський начіональний медичний університет, кафедра медицини невідкладних станів, анестезіології та інтенсивної терапї

DOI: https://doi.org/10.31435/rsglobal_wos/30042019/6445

\section{ARTICLE INFO}

Received: 19 February 2019

Accepted: 23 April 2019

Published: 30 April 2019

\section{KEYWORDS}

fibrinolysis markers, soluble fibrin-monomeric complex, elevated body mass index, polytrauma.

\begin{abstract}
The aim of our work was to analyze the dynamics of fibrinolysis markers in patients with an increased body mass index with polytrauma (IBMI). A study of complex hemostasiograms was carried out in 224 patients with IBMI during the month of hospital stay with a diagnosis of Polytrauma and on the 360th control day of the outpatient visit, which included the study of fibrinolysis indices: fibrinolysis (spontaneous) and soluble fibrin-monomeric complex (SFMK). Patients had the same severity at the time of admission on the APACHE II scale of $14 \pm 5.8$ and were divided into 3 clinical groups, depending on the starting BMI numbers. Thus, in patients with IBMI with polytrauma, dynamic disturbances in the fibrinolysis system were identified, which correspond to the course of the traumatic disease and significantly affect the functioning of the hemostasis system as a whole.
\end{abstract}

Citation: Кучерявченко В. В., Волкова Ю. В., Шарлай К. Ю. (2019) Dynamika Markeriv Fibrynolizu u Patsiientiv z Pidvyshchenym Indeksom Masy Tila pry Politravmi. International Academy Journal Web of Scholar. 4(34). doi: 10.31435/rsglobal_wos/30042019/6445

Copyright: (C) 2019 Кучерявченко В. В., Волкова Ю. В., Шарлай К. Ю. This is an open-access article distributed under the terms of the Creative Commons Attribution License (CC BY). The use, distribution or reproduction in other forums is permitted, provided the original author(s) or licensor are credited and that the original publication in this journal is cited, in accordance with accepted academic practice. No use, distribution or reproduction is permitted which does not comply with these terms.

Актуальність. Система гемостаза є однією із швидкореагучих систем організму. Зміни іiі функціонального стану, що виникають під впливом різноманітних подразників, зокрема, політравми розглідаються як прояви реакції, що спрямована на зберігання гомеостазу [1]. При цьому характер порушень, що розвиваються, може бути як пристосувальним так і патологічним [2].

Слід зауважити, що у хворих з ожирінням може відзначатися як підвищення коагуляції, так і порушення процесів фібринолізу [3]. У хворих з підвищеним індексом маси тіла (ПІМТ) через значне збільшення жирової маси відзначається порушення функції ендотелію: порушення дилатації і проліферації судин, порушення процесів тромбоутворення, фібринолізу, порушення протизапальних і антиоксидантних функцій $[4,5]$.

В останні роки підтверджено, що порушення ліпідних і вуглеводних обмінних процесів, що супроводжують ПІМТ, часто поєднуються 3 аномаліями системи тромбоутворення/ фібриноліза. Відомо, що процес фібринолізу являє собою зворотню реакцію - руйнування під впливом плазміна утвореного в результаті згортання фібрина.

Так підвищений рівень фібриногена виявляється в багатьох випадках при поєднанні ПІМТ і гіперінсулінемії, а при поєднанні ПІМТ 3 цукровим діабетом 2 типу має місце підвищення активності фактора VII згортання крові $[6,7]$. 
Важливо розуміти, що у пацієнтів 3 політравмою на фоні ПІМТ перебіг травматичної хвороби ускладнюється у зв'язку з наявністю зайвої ваги, що вимагає особливої уваги.

Метою нашої роботи був аналіз динаміки маркерів фібринолізу у пацієнтів 3 підвищеним індексом маси тіла при політравмі.

Матеріали і методи. Було проведено дослідження комплексної гемостазіограми у 224 пацієнтів з ПІМТ протягом місяця перебування у стаціонарі $з$ діагнозом «Політравма» і на 360 у контрольну добу амбулаторного візиту, яке включало вивчення показників фібринолізу: фібриноліз (спонтанний) та розчинний фібрин-мономерний комплекс (РФМК).

Пацієнти мали однакову тяжкість стану на момент находження за шкалою APACHE II $14 \pm 5,8$ балів і були розподілені на 3 стратифіковані клінічні групи в залежності від стартових цифр антропометричних показників та IMT. Так в I групу увійшли 88 пацієнтів з IMT на момент надходження до $29,9(26,1 \pm 3,1)$; в II групу - 84 хворих з IMT на момент надходження до 30,0 - 39,9 $(35,2 \pm 3,8)$; у III групу - 52 хворих з IMT на момент надходження до $>40,0$ $(46,2 \pm 5,8)$. Контрольну групу склали 60 добровольців. Дослідження проводилося на $1,3,7,14$, 30 та 360 добу від моменту отримання політравми.

Для обробки отриманих даних використовували методи параметричної статистики. Для можливості використання критерія Стьюдента обчислювали критерій Фішера-Снедекора відношення більшой дисперсії до меншої. Для з'ясування зв'язку між окремими параметрами застосовували кореляційний аналіз.

Результати дослідження. Так у хворих групи I (IMT $\leq 29,9)$ стан маркерів фібриноліза у всі строки обстеження істотно не відрізнявся від фізіологічного (мал. 1, табл. 1).

Таблиця 1. Динаміка маркерів фібриноліза у хворих з ПІМТ з травматичною хворобою

\begin{tabular}{|c|c|c|c|c|c|c|}
\hline \multirow{2}{*}{ Групи } & \multicolumn{6}{|c|}{ Строки обстеження, доба } \\
\hline & 1 & 3 & 7 & 14 & 30 & 360 \\
\hline 1. & 2. & 3. & 4. & 5. & 6. & 7. \\
\hline \multicolumn{7}{|c|}{ 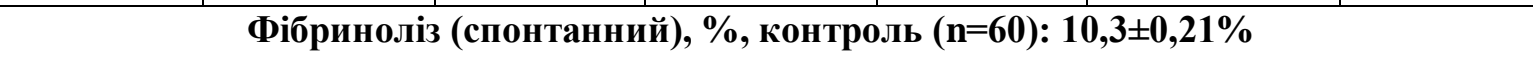 } \\
\hline Група I & $9,9 \pm 0,63$ & $10,2 \pm 0,39$ & $10,9 \pm 1,7$ & $11,4 \pm 1,7$ & $10,9 \pm 1,08$ & $11,2 \pm 1,19$ \\
\hline Група II & $8,7 \pm 0,59$ & $8,1 \pm 1,6^{*}$ & $9,2 \pm 0,36^{*}$ & $10,6 \pm 1,3$ & $11,7 \pm 1,14$ & $12,6 \pm 0,93$ \\
\hline Група III & $7,1 \pm 0,46$ & $4,8 \pm 1,8^{*}$ & $8,3 \pm 0,64 *$ & $8,1 \pm 0,92 *$ & $4,6 \pm 0,32 *$ & $9,1 \pm 0,72 *$ \\
\hline \multicolumn{7}{|c|}{ РФМК $10^{-2} / л, \mathrm{c}$, контроль $(\mathrm{n}=60): 1,6 \pm 0,29 \cdot 10^{-2} / л$} \\
\hline Група I & $4,6 \pm 1,08$ & $3,6 \pm 0,24$ & $3,2 \pm 1,48$ & $2,2 \pm 0,47$ & $1,8 \pm 0,44$ & 0 \\
\hline Група II & $4,1 \pm 1,24$ & $6,1 \pm 1,2 *$ & $5,4 \pm 1,22 *$ & $4,6 \pm 2,09$ & $3,2 \pm 0,18$ & $1,2 \pm 0,03$ \\
\hline Група III & $20,2 \pm 3,83^{*}$ & $27,6 \pm 4,1^{*}$ & $18,3 \pm 2,62^{*}$ & $11,2 \pm 2,8 *$ & $10,6 \pm 2,49 *$ & $11,4 \pm 1,19 *$ \\
\hline
\end{tabular}

В групі II (IMT 30,0 - 39,9) фібринолітична активність була знижена протягом всього раннього періода травматичної хвороби з мінімумом на 3 -ю добу - $8,1 \pm 1,6 \%(\mathrm{p}<0,05)$ і повністю відновлювалася на 30-у добу з момента отримання політравми.

У хворих групи III (IMT $\geq 40,0$ ) характерним була наявність 3 першої доби хвороби зниження фібринолітичної активності, $7,1 \pm 0,26 \%$, на 30 -у добу відбувалося різке зменшення цього показника до $4,6 \pm 0,32 \%$. Повного відновлення його не спостерігалося і у інші строки обстеження. 


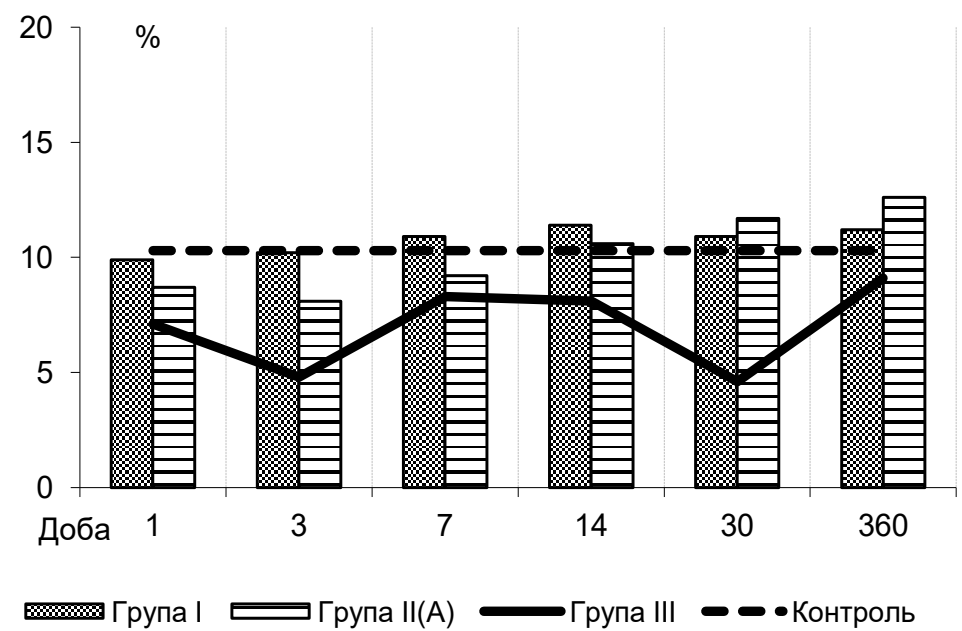

Рис. 1 Динаміка активності фібріноліза при травматичній хворобі у хворих з ПІМТ.

У пацієнтів групи I вміст РФМК в сироватці крові не відрізнявся від контрольних значень протягом всього періода обстеження (мал. 2, табл. 1).

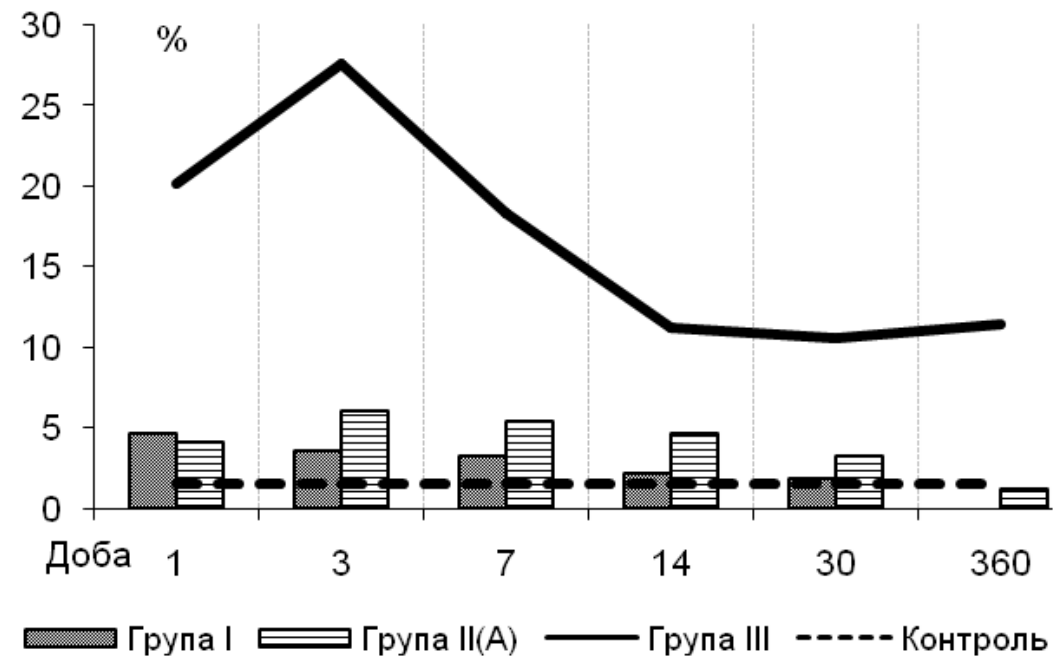

Рис. 2 Динаміка РФМК при травматичній хворобі у хворих з ПІМТ.

У хворих групи II мало місце значне їх підвищення 3 3-ї по 14-у добу 3 повним відновленням на 30-у добу.

В групі ІІІ в сиворотці виявлено значне підвищення РФМК у всі строки обстеження 3

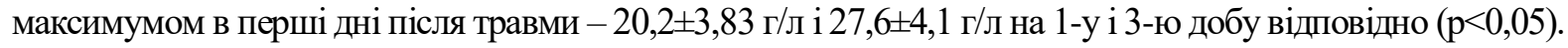

При цьому до момента закінчення обстеження - на 360-у добу - цей показник не відновлювався до належних величин, що свідчить про латентний перебіг гемостатичних порушень.

Обговорення результатів. Стан коагуляційної картини у хворих з ПІМТ в групі I (IMT $\leq 29,9)$ визначався наступними параметрами: відсутність порушень в системі фібриноліза в ранній період травматичної хвороби, що носили компенсований характер і не призводили до віддалених порушень і ускладнень з боку гемостазу. Всі отримані дані відповідали клінічному перебігу досліджуваних пацієнтів.

Для хворих групи II (IMT 30,0 - 39,9) в ранні строки - до 14-ї доби - було характерне зниження фібринолітичної активності, незначне підвищення РФМК, яке було максимальним з 1-ї по 3-ю добу. Все це свідчить на користь локального тромбогеморагічного синдрому, який проявився у $15 \%$ пацієнтів у вигляді локального тромбоза вен нижніх кінцівок, лабораторно у $32 \%$ постраждалих.

Необхідно відмітити, що саме в ці строки у 41\% пацієнтів цієї групи мали місце різні інфекційно-запальні ускладнення, які в тому числі призводили до порушень в системі гемостазу. 
Для хворих групи III (IMT $\geq 40,0)$ було характерним: в перший тиждень - накопичення в крові продуктів фібриноліза, прогресуюче зниження фібринолітичної активності. Таким чином, стійка гіперкоагуляція була виявлена у $22 \%$ хворих цієї групи. Застосування відповідної інфузійної програми - гепарин, кріоплазма, свіжоконсервованої еритроцитарної маси, введення дезагрегантів сприяло стабілізації стану у $82 \%$ хворих. Слід звернути увагу, що несприятливим щодо прогресування коагуляційних порушень виявилося значне і зростаюче в динамиці збільшення РФМК в сироватці крові, зниження фібринолітичної активності крові. Гіпостатичне положення і наявність у 40\% пацієнтів інфекційно-запальних ускладнень також загострювало процеси гемостатичного гомеостаза; в строки від 7-ї доби до 1 року у хворих цієї групи спостерігалися «мозаїчні» зсуви в системі гемостаза, що направлені на відновлення порушень гемостазу.

Висновки. Таким чином у хворих 3 ПІМТ 3 політравмою визначені динамічні порушення в системі фібриноліза, які відповідають перебігу травматичної хвороби і значно впливають на функціонування системи гемостаза в цілому. Тому, необхідно відзначити клінікопатогенетичне значення гемостазіологічних порушень при травматичній хворобі у хворих 3 ПІМТ при політравмі, характер, інтенсивність, динаміка і направленість яких визначають наслідки і можливі ускладнення, а, відповідно, і потребують специфічної кореціії.

Перспективи подалышого дослідження. Вивчення тромбоцитарної та коагуляційної ланки імунітету при травматичній хворобі у пацієнтів з підвищеним індексом маси тіла.

\section{REFERENCES}

1. Jeevanandam, M., Young, D. H., Schiller, W. R. (1991). Obesity and the metabolic response to severe multiple trauma in man. The Journal of clinical investigation, 87(1), 262-269. Doi: 10.1172/JCI114980

2. Gray, S., Dieudonne, B. (2018). Optimizing Care for Trauma Patients with Obesity. Cureus, 10(7), e3021. Doi:10.7759/cureus.3021

3. Kornblith, L.Z., Howard, B., Kunitake, R. (2015). Obesity and clotting: Body mass index independently contributes to hypercoagulability after injury. J Trauma Acute Care Surg, 78(1), 30-6. Doi: 10.1097/TA.0000000000000490

4. Andruszkow, H., Veh, J., Mommsen, P., Zeckey, C., Hildebrand, F., Frink, M. (2013). Impact of the body mass on complications and outcome in multiple trauma patients: what does the weight weigh? Mediators Inflamm, 2013, 345702. Doi: 10.1155/2013/345702

5. Premaor, M. O., Comim, F. V., Compston, J. E. (2014). Obesity and fractures. Arq Bras Endocrinol Metabol, 58(5), 470-477. Doi: 10.1590/0004-2730000003274.

6. Dhungel, V., Liao, J., Raut, H., Lilienthal, M. A., Garcia, L. J., Born, J., Choi, K. C. (2015). Obesity delays functional recovery in trauma patients. J Surg Res, 193(1), 415-420. Doi: 10.1016/j.jss.2014.07.027.

7. Osborne, Z., Rowitz, B., Moore, H., Oliphant, U., Butler, J., Olson, M., Aucar, J. (2014). Obesity in trauma: outcomes and disposition trends. Am J Surg, 207(3), 387-392. Doi: 10.1016/j.amjsurg.2013.10.013. 